\title{
Managerial Ownership and Firm Value of Selected Nigeria Listed Manufacturing Companies: Does Dividend Payment Policy Really Mediate?
}

\section{Article History}

Received: 17 August, 2020

Revised: 06 October, 2021

Accepted: 13 October, 2021

Published: 20 October, 2021

Copyright $\odot 2021$ Noble Academic Publisher \& Author

\author{
FALADE, Abidemi Olufemi Olusegun* \\ Senate Research Consulting Firm
}

NEJO, Femi Michael

(Economics Department, Adekunle Ajasin University, Akungba Akoko)

GBEMIGUN, Catherine Omoleye

Dept. Accounting, Adekunle Ajasin University, Akungba-Akoko

\begin{abstract}
Shareholders play a vital role in an organization through parting with their funds which determines the continuity and survival of the organization. As a result of this, regular payment of dividends as at when due to different shareholders is a concerned of every stakeholder in an organization. Therefore, this study examined the mediating effect of dividend payment policy on the relationship between managerial ownership and firm value of listed manufacturing companies in Nigeria. This study focused on ten manufacturing firms that are listed on Nigeria Stock Exchange (NSE) from 2010 to 2019 using panel pool technique and Hausman's test. The findings from this study established that there was a partial mediation of managerial ownership, dividend payout and leverage ratio on firm value. In addition, managerial ownership (20.8\%) had an inverse and significant effect on firm value; while, dividend payout ratio and leverage ratio had a direct and significant effect on it with each contributing $15.2 \%$ and $3.8 \%$ to it respectively. On mediation, the finding discovered that dividend payout through managerial ownership indirectly contributed $33.1 \%$ to managerial ownership. The study concluded that managerial ownership and dividend payment policy partly contributed to firm value with dividend payment policy playing an indirect role through increase in managerial ownership. Therefore, recommended that organizations should endeavor to review their dividend payment policy and ensure that dividend accrue to the firms' coffer are pay as at when due. Also, managers of listed firms are strongly advised to take more of long-term loan on intending capital projects.
\end{abstract}

Key words: Dividend Payment Policy (DPP), Firm Value, Managerial Ownership, Panel Pool Technique and Hausman Test.

\section{Introduction}

Every corporate organization especially listed manufacturing companies are established to add utility to unfinished product and protect the stakeholders' interest. An organization comprises of both primary stakeholders and secondary stakeholders. According to Ishola and Ishola (2019), the primary stakeholders are people that their continuing participation determine the existence of the organization, these stakeholders include shareholders, management and employees. The secondary stakeholders are people that the organization activities affected or influenced but are not engaged in the organization activities. In business world, among stakeholders is the shareholder that is also known as stockholder which owns a share of a company stock or equity. In the world of Rahman (2018), every stakeholder plays a vital role in an organization but shareholder perform the core role through parting with their funds to determine the continuity and survival of an organization. (Nduta, 2016) remarks that when organization makes profit or loss, the shareholders of such organization bear it. According to Lihard and Ramon-Arthur (2017), maximization of shareholder's wealth is the typical drive of corporate organization. Achieving shareholder's wealth hinges on many factors. For instance, Lihard and Ramon-Arthur (2017) reveal that value of a business otherwise known as firm value goes a long way in determine the portion of profit to be given to each shareholders in an organization. The dividend policy is concerned with the percentage of profit an organization decides to given its shareholder or retained for continuity of the organization. Given this, Priya K. and Nimalathasan (2013) stress that the choice to pay out profits versus retaining and reinvesting them serves as an important indicator for firm value.

A large organization like listed firm need a manager that have a substantial ownership knowledge based to make decisions which are in the best interest of shareholders before maximization of shareholder's wealth. According to Rahman (2018), manager and other decision making body in an organization make certain three main decisions that include financing decision, investment decision, and 
dividend decision. In dividend decision, firm value plays a vital role in measuring the percentage of equity share owned by directors and others (managerial ownership). According to Walter (1963), in the Bird- inHand theory, increase in dividend payment to each shareholder in any organization is connected with the high value of the business worth at a particular period of time. Meanwhile, the sum of dividends distribute among shareholders within an organization depends on the dividend policy adopted by each company. For instance, the Proportion of Net Income After Tax that an organization distributes as dividend is often presented in Dividend Pay Out Ratio (DPR) that determines the amount of dividend per share (Dividend Per Share). According to Lihard and Ramon-Arthur (2017), dividend policy is a robust determinant factor for firm value, such that, a large dividend payment to each increases the stock price which directly influence the firm value. In view of this, it is established that a firm's choice of dividend policy does not necessary influence shareholders' wealth due to the fact that the value of the firm is determined by its earnings and investment strategy and not the way the earnings are shared among different shareholders (Maladjian and Rim, 2014; Miller and Modigliani, 1961; Moeljadi., 2014; Muriungi and Mwangi, 2020).

Managerial ownership is concerned with the ratio of shares owned by all board members to total shares outstanding. The managerial ownership on firm value have been of particular research interest especially in the corporate finance literature. According to Agency theory as propounded by Jensen M. C. and Meckling (1976), separation of control and ownership gives rise to a conflict of interest between different stakeholders present in an organization with managers first protecting owners' interest at early stage and possibilities conflict interests between the duo at the latter stage. In view of this, Muriungi and Mwangi (2020) suggest that increase in volume of retained earnings often indulge managers to pursue their interest which often make shareholders to minimize the sum of funds accessible to managers, in order to reduce or eliminate the ideology of protecting their self-interest. Also, Ruan et al. (2011) supported the above claims and reveal that more increase in the equity or share acquired by management to some certain level increases its shares value (managerial ownership) which may give room to manager to pursue self-benefit without concern for increase in firm value. Also, Jensen M. (1986) and Rozeff (1982) claimed that non-payment of dividends to the organization's shareholders within some certain period could allow the designated managers to use these resources for their private benefits. Thus, Hamid and Shafiullah (2012) suggest that regular payment of dividends as at when due to different shareholders in an organization reduce the managerial control over the available resources.

In 1960, Nigerian Stock Exchange was founded and known then as the Lagos Stock Exchange and later changed to the name Nigerian Stock Exchange in 1977. As at December, 2019, there were fortythree listed manufacturing companies on the stock exchange markets with a total annual market capitalization of $25,890.22$ billion naira Lebi (2021). Furthermore, the market makes a long-term fund available for the listed manufacturing firms which directly influence their firm value. Hence, the question of dividend payment, managerial ownership and improvement in firm value are all pointing toward listed firm. In view of this, this present study examines the mediating role of dividend payment policy on the relationship between managerial ownership and firm value of listed manufacturing companies in Nigeria. The organization of the study include introduction, literature review, theoretical framework, result and discussion and conclusion and recommendation.

\section{Statement of the Problem}

Listed manufacturing firms are often owned by private organization with the sole aim of making profit and adding utility to unfinished product through transformation of such products to finished goods. Achieving this require capital from the primary stakeholder's (shareholders or institutional investors) with the sole aim of distributing some of the company's earnings to a class of its shareholders as determined by the company's board of director. In view of this, Rahman (2018) reveals that assurance of dividend payment encourage shareholder to invest in business as well as measurement of actuality to the investors as regard the firm financial performance. Also, Jensen M. (1986) and Rozeff (1982) remark that dividend payment need to be distributed across board in order to eliminate the idea of using such for private benefits. Meanwhile, managerial ownership and firm size has been extensively studies in the literature with most of this studies confirmed that managers' and shareholders' interests are not fully aligned. For instance, Ruan et al. (2011) reveal that more increase in the equity or share acquired by management to some certain level increases its shares value (managerial ownership) which may give room to manager to pursue self-benefit without concern for increase in firm value. Also, Hamid and Shafiullah (2012) remarks that regular payment of dividends as at when due to different shareholders in an organization reduce the firm value. Despite numerous findings, one question that seems not yet answered among listed manufacturing firms in Nigeria is that, as firms' value increases as claims by previous studies, what 
mediating role does dividend payment policy play? Hence, bring the need for the introduction of dividend payment policy as moderating variable to examine effect of managerial ownership on firm value of listed manufacturing companies in Nigeria.

\section{Research Hypotheses}

The following hypotheses are stated in their null form;

$\mathbf{H O}_{1}$ : Managerial ownership has no significant effect on firm value of listed manufacturing companies in Nigeria.

$\mathbf{H O}_{2}$ : Dividend payment policy has no significant indirect role on firm value of listed manufacturing companies in Nigeria.

\section{Literature Review}

\subsection{Dividend Payment Policy}

According to Lihard and Ramon-Arthur (2017), Dividend Payment Policy (DPP) is basically the portion of the profit given to the shareholders. In the word of Rahman (2018), DPP are cash disbursements which are made to the shareholders against their investment in the business. In this study, DPP is the method adopted by an organization in distributing or payment of company's profit to its shareholders. The methods adopting in dividend payment could either be cash dividends or stock dividends, depending on the firm policy. The cash dividend involves payment of dividend by cash to shareholders; while, stock dividends is concerned with dividend payment made to shareholders in form of shares rather than as cash. In listed firms, improvement in dividends of a company play an important role for primary stakeholders, secondary stakeholder and investor. For instance, primary stakeholders like shareholders receive more dividend; secondary stakeholder like host community benefit more of corporate social responsibility; while investors are motivated to invest in such company. Rahman (2018) also identified two importance of dividend to involved measurement of actuality to the investors as regard the firm financial interest and a green signal for the future performance of the firm in the market.

Meanwhile, DPP has been explored for many decades with no universally accepted explanation for companies' observed dividend behaviour has been established (Samuel and Edward, 2011). For instance, Miller and Modigliani (1961) argued that dividend decision does not affect the value of a firm and is, hence, unimportant. Yet, traditional adherents suggest that there is need for proper management of dividend policy among the shareholders because it can affect share prices and shareholder's wealth (Rahman, 2018). Also, many theories have been formulated to explain the dynamic of dividend policies such as the bird-in-hand theory, Modigliani and Miller (M\&M) etc.

\subsection{Firm Value}

Wahyudi and Pawestri (2006) defined firm value as the exact amount the potential buyers is willing and ready to pay if the firm was to be liquidated. Sundaram and Inkpen (2004) sees firm value maximization as a decision making process which brings benefits to all stakeholders. From this study, firm value is concerned with the overall value of a company. It is also known as enterprise value and it is more comprehensive in measuring total value or worth of a company than equity. According to Ahmad and Abdul Aziz (2017), firm value is often determined by both endogenous and exogenous factors. Among the identified endogenous factor include market capitalization, profitability, solvency and growth opportunities. In the word of Marvadi (2015), firm management has the ability to influence the exogenous factors, unlike endogenous factor that is outside their power. Tobin's Q is adopted as a method use to proxy firm value. Tobin's Q was first introduced into the literature in 1966 by Kaldor (1966). According to Kaldor (1966), Tobin's Q is measure as the ratio between a physical asset's market value and its replacement value (reproduction cost).

Also, Meragal and Senadheera (2016) disclose that size variable is directly influence the value of the firms. Both local and international investors invest their resource in large corporation especially listed for firm for marketability of their shares, diversification purpose, reduction of risk and low production cost. According to the shareholder theory, performance of a firm is usually measured through maximization of owners' value. This implies that maximization of the value increase equity and thereby increasing the shareholder's wealth. Haryono and Paminto (2015) discloses that maximization of firm value increase shareholders through increase in firm value. Panji and Elan (2018) disclose that value 
maximization in listed firm is more superior than profitability. This is attributed to the fact that maximization of organization value is a requisite for wealth maximization.

\subsection{Managerial Ownership}

Managerial ownership is the ratio of shares each board member owned to total shares outstanding. The investment theory has identified two opposing effects of managerial ownership that include the incentive and the entrenchment effect. The incentive effect is concerned with a positive performance of a firm in the process of measuring its policies, operations in monetary terms and nonfinancial indicators; while, entrench effect allows is concerned with little contribution from other shareholders due to large percentage of shares held by ownership. Mueller and Spitz (2014) attributed incentive effect to when both ownership and other shareholders have equal stake in the business. Entrenchment effect often occurs when managers with large ownership shares have high managerial ownership shares, therefore, entrench themselves and difficult for other shareholders to take decision. According Meanwhile, Muriungi and Mwangi (2020) remark that increase in volume of retained earnings often indulge managers to pursue their interest which often make shareholders to minimize the sum of funds accessible to managers in order to reduce or eliminate the ideology of protecting their self-interest. Also, Hamid and Shafiullah (2012) stress that organization need to adopt regular payment in order to discourage the use of resources for personal gain by the managers. For an organization listed on stock market, what determines percentage of share owned by board member is the ownership structure which is concerned with votes and capital, but also by the identity of the equity owners. The crucial objective of private owned organization is to increase (maximize) its shareholders' wealth or value. Shareholder's wealth can be increased by both getting dividends or having capital.

In the process of managing ownership, the theoretical literature differentiates between insiders and outsiders; management ownership. The outsiders are considered as people who manage the company; while, outsiders are often regarded as suppliers of funds to the company (Jensen M. C. and Meckling, 1976). Inside managers adopt investment tactics to improve their own wealth share but lessen the payment receive by outside suppliers of funds. This behaviour is achieved through higher managerial ownership because this increases the costs that managers have to bear (incentive effect). Also, for a given ownership distribution, the higher the level of managerial ownership, the more difficult it is for outsiders to control the management (Ang et al., 2000). Therefore, in the process people assigned into management position has often likely to "entrench" themselves. Taking the incentive hypothesis and the entrenchment hypothesis into account, the relationship between management's ownership share and company performance can be non-linear. At low levels of ownership, the incentive effect can be dominant, that is, there is a positive effect. However, at very high levels of ownership the entrenchment effect might be more important and the effect of ownership could be negative.

It is extensively believed that more increase in managerial ownership is cherished among shareholders because it supports the interests of directors better with those of shareholders. Meanwhile, there is a substantial literature dedicated to understanding the effect of managerial ownership on firm value. Many of those studies built the studies on the agency literature (Jensen M. C. and Meckling, 1976; Stulz, 1988). In these studies, it is believed that increase in managerial ownership induce managers' incentives and benefits each shareholders present in an organization which improve firm value. But increase in managerial ownership beyond sum certain threshold drastically affect firm value due to what the studies refer to entrenchment effect (personal gain). Rudiger and Rene (2009) attributed this fact to non- monotonic relationship and optimal level of ownership between firm value and managerial ownership in listed firm.

\section{Conceptual Framework}

A framework that deal with the diagrammatic presentation of identified variable used to established the mediating role of dividend payment policy on the nexus between managerial ownership and firm value is shown below in figure 2. Firm value acts as the exogenous variables, while, both dividend payout (proxy for DPP) and managerial ownership are the endogenous variables. 
Figure 2. Single Mediator Diagram

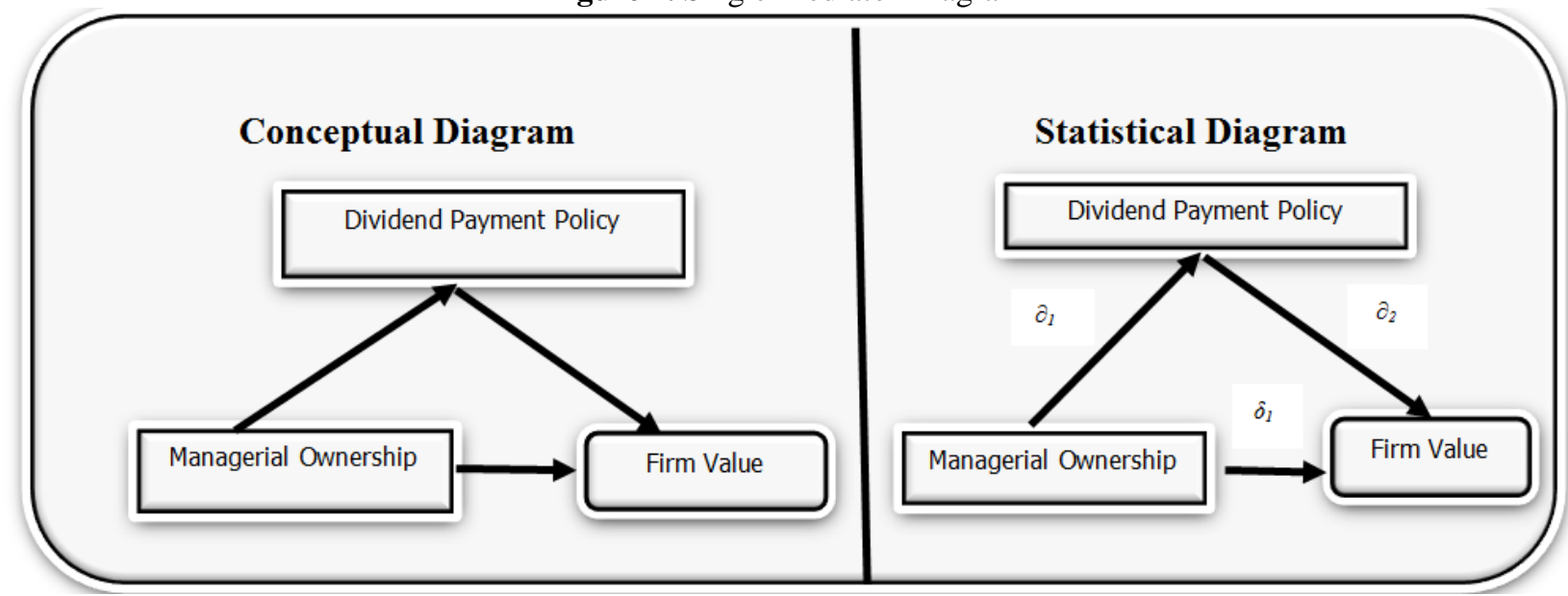

Sources: Researcher's compilation (2021)

In the diagram above in figure 2, both the $\partial_{1}$ and $\partial_{2}$ are mediated effect. Thus, the mediated effect reflects the extent to which the managerial ownership (independent variable) changes the dividend payment policy (mediator) and the extent to which the mediator changes the firm value (dependent variable).

\section{Theoretical Framework}

\subsection{Bird In Hand Theory}

This study adopted bird in hand theory as propounded by Lintner (1956). According to the theory individual shareholder in an organization would prefer dividend payment rather than having capital gains because each shareholder belief that today's dividend is more profitable than the future capital gains. In the word of Walter (1963), organization's shareholders often prefer to accept dividends now and reinvest such dividend on other investments for future better earning. Jensen M. (1986) and Rozeff (1982) discovered that there is need for shareholders in an organization to receive their dividend often without that, such resources would be used for managers' private benefits. In view of this, Hamid and Shafiullah (2012) remarks that regular payment of dividends as at when due to different shareholders in an organization reduce the managerial control over the available resources. Also, the theory assumes that collection of dividend reduces information asymmetry between different players in the market. Muriungi and Mwangi (2020) suggest that a firm that pays dividend assures investors that the firm is performing well which reduces risks associated with investments because it is more certain.

\section{Empirical Studies}

\subsection{Managerial Ownership and Firm Value}

Panji and Elan (2018) on managerial ownership, profitability and firm value used a multiple regression technique and data from 2012 to 2015 on food and beverage industrial sector. It was confirmed through the result that managerial ownership was indeed a significant and direct variable that influence firm value of the selected companies with profitability displacing indirect and significant effect on it. Sang-Mook and Keunkwan (2003) adopted panel data approach affirmed that indeed a non-significant and direct association existed between the management ownership and firm value. Tian et al. (2009) used OLS technique on 500 firm. The OLS result affirmed that managerial ownership had no influenced on firm value but direct association occurred with capital structure directly determined firm value and managerial ownership. A study carried out in China by Wenjuan et al. (2009) from 2002 - 2007 adopted OLS technique. The OLS showed that managerial ownership had an inverse effect on firm value. On dynamic of Managerial ownership Rudiger and Rene (2009) used 1988-2003 as scope with the result showing that an indirect effect existed between the duo with the conclusion that managers in an organization are likely to reduce their ownership when there is improvement in firm value and more likely to increase their ownership when their firms become financially constrained. Duc and Van (2014) investigated managerial ownership, leverage and dividend policies among listed firms in Vietnam using three-stage least squares (3SLS) and 81 listed firms from 2007-2012. The 3SLS results showed that managerial ownership was significant with an inverse effect on leverage ratio. The finding was consistent with Agency theory and Pecking order theory. Also, it was established that managerial ownership was 
directly related to dividend payment. Also, Mohammad et al. (2013) study ownership structure and dividends policy in Jordanian companies using 35 listed corporations on Amman Stock Exchange from 2005-2010. The study adopted Full Adjustment Model and Partial Adjustment Model techniques. The results revealed that institutional ownership was significant with a direct effect on dividend policy payment; while, managerial ownership was significant with an indirect effect on it. Similar study was carried out by Thanatawee (2013) in Thailand and 1,927 sample from 2002-2010 arrived at the same conclusion with the conclusion higher ownership concentration increase dividends payment. On ownership and dividend policy, a study was carried out by Mahdi and Alireza (2017) using Tehran Stock Exchange as the case study from 2002-2016. It was observed from estimated result that institutional and corporate investors had a direct and significant effect the dividend policy at the conventional level of 5\%, in addition, net income and firm size were not significant. Similar study by Sindhu et al. (2016) in Karachi stock exchange for the period of 2011-2015 used 100 companies related. The study used panel pool data with the confirmation of fixed effects through Hausman's test. The result confirmed that managerial ownership had a significant and inversely related to dividend payout ratio. While, institutional ownership and firm's size were directly related to dividend payout ratio.

\section{Dividends Policy and Firms Value}

Gitagia et al. (2020) concentrated on listed firms on Nairobi Securities Exchange Kenya from 2008-2016 using 46 non-financial companies and Feasible Generalized Least Square (FGLS) for the study. The FGLS, showed that dividend decisions was indeed a robust determinant factor that influenced firm value with Whisman showed that GDP performed moderating significant role between dividend decisions and the firm value. Linna (2018) used a firm-level panel data to study how capital structure responds to dividends policy among listed in Indonesian Stock Exchange Market from 2010-2015. The discovery showed that there was a partial influenced of capital structure on firm's value; while, dividend's policy showed a sign of non-significant on firm's value. In addition, it was confirmed that simultaneously that both capital structure and dividend's policy had effect on it. A study by Priya P. V. and Mohanasundari (2016) on similar subject using a review and empirical study of Miller and Modigliani, signaling, bird-in-the-hand, agency costs hypotheses, tax-preference and clientele effects concluded that dividend payment policy had both significant and non-significant effect on firm value depending on the school of thought the study is premised. Sourav et al. (2020) used 500 listed companies from 2001-2017 and Generalized Method of Moments (GMM) technique. The GMM showed that dividend policy had no statistical effect on firm value with financial crisis directly influenced the degree of association between the duo. Also, Anton (2016) used a panel technique approach from 2001-2011 on listed firm in Bucharest Stock Exchange. The fixed effects technique through Hausman's result was used to confirmed that dividend pay-out ratio was a robust determinant of firm value with leverage ratio showing the same direct and significant sign with firm value. Rahman (2018) studied dividend policy and its impact on firm performance using cement sector listed on Pakistan Stock Exchange from 2012 to 2016. From the OLS result, it was confirmed that a direct and non-significant effect was established between return on equity and dividend per share. Also, firm value, firm size and earning per share had a direct and significant effect on return-on-equity; while, financial leverage was insignificant. Similar study by Rachid and Wiame (2016) using selected listed firms from Morocco discovered that a direct and significant effect of dividend policy on firm performance. The study concluded that dividend policy is a robust determinant for firm performance for listed firms in Morocco. Hamid and Shafiullah (2012) examined ownership structure and dividend policy evidence in listed firm in Pakistan in the context of agency relation. The Stepwise empirical multiple regression showed that a significant and an inverse relationship between dividend payouts and managerial share ownership. Also, a direct and significant effect was established between institutional and foreign share ownership. The study concluded that ownership structure drastically reduces dividend policy which serves as too to minimize the agency problem. In the same way, Harada and Nguyen (2011) carried out a study using listed firms on Japanese. The study discovered that ownership concentration is associated with significantly lower dividends in proportion of earnings as well as in proportion of equity.

\section{Financial Leverage and Firm Value}

Kuben (2008) sampled 113 listed firm on the Johannesburg Stock Exchange (JSE) from 1998-2007. The technique used affirmed that financial leverage was significant and increase in it decrease firm value with interest rate showing sign of non-significant effect. Adenugba et al. (2016) studied some selected listed firms on Nigerian Stock Exchange (NSE) form 2007-2012 using OLS. The OLS result re-affirmed 
that financial leverage positively contributed to firm value because it better in financing long-term debt than other form of equity. Umar and Abdul-Qudus (2020) used selected firm on Nigerian Stock Exchange as the case study from 2014-2018. The sampled 18 firms with Pooled Ordinary Least Squares showed that leverage directly improved firm value. Akani and Kenn-Ndubuisi (2017) had a contrary result with the discovery that financial leverage indirectly reduced firm value when there is increase in it. Also, pairwise correlation showed confirmed a non-significant liner association between the duo. Ming-Chang and Zuwei-Ching (2011) used 645 listed in Taiwan from 2000-2009 and GMM. The GMM confirmed that leverage was significant and directly related to firm value with improvement in leverage ratio have a similar proportion on firm value. Also, Meragal and Senadheera (2016) adopting 2011-2015 period in Sri Lanka by with the 50 observed firms showed a non-significant relationship between the duo.

\section{Methodology}

This study focused on ten manufacturing firms that are listed on Nigerian Stock Exchange (NSE) which include Unilever Nigeria Plc, Lafarge Africa, Guinness Nigeria Plc, Nigeria Breweries, PZ Cusson, Nestle Plc, Dangote Sugar Refinery, Four Mills of Nigeria, Dufil Prima foods, and Cadbury Plc. The secondary data used was sourced from annual reports of the selected firms for a period of 10 years, spanning from 2010 to 2019. The rationale behind the selection of the manufacturing firms was because of their larger contribution to Nigeria's gross domestic product annually.

The model for this study was built on Gitagia et al. (2020) model. The basic model for Gitagia et al. (2020) is given below as;

$F V=F(D D) \ldots$

Wher : FV is the firm value, DD denotes a vector of Dividend decisions

The modified model for this study is given below as;

$F V A L U E=f(M A G O) \ldots . \ldots . \ldots i i$

Introduction of moderating variable into equation ii, we have;

FVALUE $=f(M A G O, D I V R) \ldots \ldots . . . . i i i$

According to Lintner (1956) theory of Bird in Hand, collection of dividend reduces information asymmetry between different players in the market, therefore, allows firms to determine either to use equity, loan or both to financial its operation. In view of this, debt and equity that was proxy as leverage ratio was included in equation iii. Thus, we have;

FVALUE $=f(M A G O$, DIVR, LEVR) $\ldots \ldots \ldots \ldots$ iv

Where: FVALUE= Firm value, $M A G O=$ Managerial ownership DIVR= Dividend payout ratio, $L E V R=$ Leverage ratio

The econometric form of equation iv above is given below as

$F V A L U E=\partial_{o}+\partial_{1} M A G O+\partial_{2} D I V R+\partial_{3} L E V R+\mu \ldots \ldots \ldots(v)$

The a-priori expectation is: $\partial_{1}<0, \partial_{2}>0$ and $\partial_{3}>0$

Calculating for the indirect effect of the moderating variable, the study adopted Judd and Kenny (1981) difference of coefficients approach. Therefore, the study has the following;

$F V A L U E_{t}=f\left(M A G O_{t}\right.$

The econometric form of equation vi above is given below

FVALUE $_{t}=\delta_{o}+\delta_{1} M_{1} \mathrm{MAO}_{t}+v \ldots \ldots \quad \ldots \quad \ldots$ (vii)

The study adopted a panel least squares approach techniques to examine the nexus between the dependent and independent variables with the inclusion of mediating variables. The rationale behind 
applying the technique was that it reduces the mean squared errors of the parameter estimators and improves testing power by exploiting the serial and cross-equation correlations in the data Gujarati et al. (2012).

Table 1. Measurement of Variables

\begin{tabular}{|l|l|l|}
\hline Variables & Measurement & Source \\
\hline MAGO & $\begin{array}{l}\text { Number of shares held by directors and } \\
\text { members of the board / total outstanding shares }\end{array}$ & Duc and Van (2014) \\
\hline FVALUE & $\begin{array}{l}\text { the ratio of the market value of a company's } \\
\text { assets/ the replacement cost of the company's } \\
\text { assets }\end{array}$ & Researcher's computation \\
\hline DIVR & $\begin{array}{l}\text { Total Dividends / Total Net Earnings x 100\% } \\
\text { LEVAG }\end{array}$ Total debt divided by total assets & $\begin{array}{l}\text { Rahman (2018), Duc and Van (2014), } \\
\text { Priya K. and Nimalathasan (2013), }\end{array}$ \\
\hline
\end{tabular}

Source: Researcher's compilation, (2021)

\section{Results and Discussions}

Table 2. Correlation Matrix

\begin{tabular}{|l|l|l|l|l|}
\hline Variables & FVALUE & MAGO & DIVR & LEVR \\
\hline FVALUE & 1.00000 & & & \\
\hline MAGO & -0.368664 & 1.000000 & & \\
\hline & 0.0636 & & & \\
\hline DIVR & 0.168852 & 2.785559 & 1.000000 & \\
\hline & 0.0045 & 0.0332 & & \\
\hline LEVR & 0.751203 & 0.373805 & 0.277625 & 1.000000 \\
\hline & 0.0567 & 0.0559 & 0.0232 & \\
\hline
\end{tabular}

Source: Researcher's compilation from Eview-9 (2021)

The result of correlation matrix shown in table 2 confirmed that the estimated coefficient of firm value (FVALUE) was in-line with the assumption of Pearson's correlation with a perfect correlation of 1. This finding implies that improvement in firm value of selected manufacturing companies was $100 \%$ attributed to increase in overall value of the listed firms.

For the managerial ownership, it was significant and indirectly related to firm value with a moderate coefficient approximate to 0.3686 at $10 \%$ significance value. Therefore, implies that the impact of managerial ownership on firm value was significance. The implication of this is that decrease in firm value of selected manufacturing companies was attributed $30.5 \%$ shares owned by all board members couple with the total outstanding shares.

Also, the degree of association between dividend payout ratio (DIVR) and firm value was directly related with a moderate degree coefficient value approximate to 0.168852 at $5 \%$ significance level. This therefore, shows that a direct relationship occurred between dividend payout ratio and firm value with a dividend payout ratio having moderate impact on firm value. The implication of this finding is that $16.9 \%$ increase in worth of listed manufacturing companies was attributed to dividend payment policy adopted. This finding was consistent with bird in hand theory as propounded by Lintner (1956) that assumes that individual shareholder in an organization would prefer dividend payment to capital gains.

Also, a direct association was established between leverage ratio and firm value with a high degree association of $75.1 \%$ and $p$-value less than $5 \%$ significance level. This suggested that improvement that occurred in firm value could be attributed $75.1 \%$ increase in total debt to total asset owned by the selected firms.

Table 3. Hausman Test

\begin{tabular}{|l|l|l|l|} 
Test Summary & Chi-Sq. Statistic & Chi-Sq. d. & Prob \\
\hline Cross-section random & 6.567273 & 3 & 0.8170 \\
\hline
\end{tabular}

Source: Researcher's Compilation, 2021 from E-view-9

The p-value of Hausman test in Table 3 was greater than 5\% and $10 \%$ conventional level. Therefore, implies that random effect model was appropriate in explaining the variation that occur between the dependent and the independent variables. 
Table 5. Random Effect Result

\begin{tabular}{|c|c|c|c|c|}
\hline \multicolumn{5}{|c|}{$\begin{array}{l}R^{2}=0.660318 ; \text { Adjusted } R^{2}=0.573242 ; \operatorname{Prob}(F \text {-statistic })=0.032838 ; \text { Durbin-Watson } \text { stat }= \\
1.854631\end{array}$} \\
\hline Variable & Coefficient & Std. Error & t-Statistic & Prob. \\
\hline MAGO & -0.2081 & 0.1122 & -1.8549 & $0.0698 *$ \\
\hline DIVR & 0.1518 & 0.0634 & 2.3949 & $0.0112 * *$ \\
\hline LEVR & 0.0376 & 0.0158 & 2.3787 & $0.0208 * *$ \\
\hline Constant & 49.051 & 5.6565 & 8.6716 & $0.0000 * *$ \\
\hline
\end{tabular}

Source: Researcher's Compilation, 2021 from E-view-9

The results of the random effect showed that estimated value of managerial ownership had an indirect and significant effect on firm value with an absolute co-efficient values of $20.8 \%$ and $p$-value of 0.0698. This shows that provided other factors that affect firm value were kept constant, managerial ownership indirectly influenced firm value. The significance nature of managerial ownership has two implications on firm value. First, distribution of retained earnings among different shareholders of listed firms reduce the expansion of business's operation through retained earnings, therefore, reduces firm's worth. Also, increase in the ratio of shares owned by each board member of the listed firms often determine the dividend policy used to distribute share which drastically reduce firms value. However, the a- priori expectation was consistent with the theory adopted for this study which is bird in hand theory as propounded by Lintner (1956) that assumes that individual shareholder in an organization would prefer dividend payment rather than having capital gains because each shareholder belief that today's dividend is more profitable than the future capital gains. The inverse sign of the duo could also be attribute to the claims that increase in volume of retained earnings often indulge managers to pursue their interest which often make shareholders to minimize the sum of funds accessible to managers for the purpose of selfinterest. Given this, studies like Muriungi and Mwangi (2020), Ruan et al. (2011) and Jensen M. C. and Meckling (1976) have come to conclusion that retained earnings should be shared among different shareholders in an organization because share acquired by management to some certain level may give room to manager to pursue self-benefit without concern for increase in firm value. This finding concurred with the works of Rudiger and Rene (2009) and Wenjuan et al. (2009) that showed that managerial ownership had a significant and an inverse effect on firm value. On a contrary note, study by Panji and Elan (2018) showed an indirect and significant effect between them with Tian et al. (2009) and SangMook and Keunkwan (2003) establishing a non-significant and direct association between them.

The result for the dividend payout was significant with a coefficient value of $15.2 \%$ and a $p$-value less than 5\%. This implies that dividend payout was significant at $5 \%$ significance level with a direct effect on firm value. In finance, its implications on firm value is that regular payment of dividends as at when due to different shareholders in the selected manufacturing companies increases business worth of the firm. The reason for this could be attributed to the fact that dividends received are channel to others productivity investment that would improve business worth. In view of this, (Muriungi and Mwangi (2020)), Jensen M. (1986) and Rozeff (1982) remark that dividends should be shared among different shareholders in an organization in order to encourage investors which directly influence business worth. The finding was consistent with the formulate $a$ - priori expectation. Gitagia et al. (2020) and Anton (2016) confirmed with the above finding and showed that dividend decisions was indeed a robust determinant factor that influenced firm value; while, Sourav et al. (2020), Linna (2018) discovered dividends policy had non-significant influence on firm's value.

On leverage ratio, it was confirmed that leverage ratio was significant and had a direct effect on firm value with a co-efficient value of $3.76 \%$ and $p$-value $(0.0208)$ that was less than 0.05 level. The implication of this is that financial leverage is more beneficial and productivity in financing long-term project of firm than equity of the listed firms. This reason for this is that increase in ratio of a company's debt (loan capital) to the value of the sum of non-current and current assets directly influence firm value of the selected manufacturing companies in Nigeria. This finding was consistency with the theory of bird in hand as propounded by Lintner (1956) on which the $a$ - priori expectation was built on. The significance nature of leverage ratio could be attributed to the provision of long-term loan by Nigeria financial institutions such as capital market as well as capital structure (debt-equity). For instance, in a situation where a long-term loan that is more than 90 days' maturity is given to manufacturing companies, it increases the return on assets of manufacturing sector which improve firm value. This finding was 
consistency with the work of Umar and Abdul-Qudus (2020), Adenugba et al. (2016) and Ming-Chang and Zuwei-Ching (2011) that re-affirmed that financial leverage positively contributed to firm value because it better in financing long-term debt than other form of equity. On a contrary Akani and KennNdubuisi (2017) and Kuben (2008) discovered that financial leverage indirectly reduced firm value when there is increase in it.

The value of the adjusted $\mathrm{R}^{2}$ implies that the three identified independent variables (managerial ownership, dividend payout ratio and leverage ratio) explained exactly about $57.3 \%$ variation in firm value; while, the remaining $42.7 \%$ was attributed to random term.

\section{Calculating the Indirect Effect}

The Judd and Kenny (1981) approach involves subtracting the partial regression coefficient obtained in equation (v) from equation (vi)

\begin{tabular}{|l|l|}
\hline Judd \& Kenny Difference of Coefficients Approach \\
\hline Equation & Analysis \\
\hline Equation v & $49.051-0.2081 \mathrm{MAGO}_{\mathrm{t}}-0.1518 \mathrm{DIVR}+0.0376 \mathrm{LEVR}+0.427$ \\
\hline Equation vi & $F V A L U E_{t}=\delta_{o}+0.1231 \mathrm{MAGO}_{\mathrm{t}}+0.8963$ \\
\hline
\end{tabular}

Source: Research's compilation using Judd \& Kenny Approach

$I=\delta_{1}-\partial_{1} \ldots \ldots \ldots \ldots \ldots($ vii $)$

Where $; \delta_{1}=$ Estimated $M A G O_{t}, \partial_{1}=$ Estimated $M A G O_{t}$, and $I=$ Indirect

\begin{tabular}{|l|l|l|}
\hline Estimated indirect effect & Standard Error & Ratio I/ Standard Error \\
\hline$I=0.1231+0.2081=0.3312$ & 1.7231 & 1.0154 \\
\hline
\end{tabular}

Source: Researcher's compilation

The estimated result of indirect effect of dividend payout ratio (0.3312) was statistically significant judging from the standard error (1.0154) and the critical values (2.042) that were significantly different from zero. This implies that the proportion of dividend payout through firm value indirectly contributed $33.1 \%$ to the aggregate level of firm value in the selected manufacturing listed companies in Nigeria. The implication of this is that increase in business worth of the selected manufacturing companies was $33.1 \%$ attributed to indirect role played by dividend payment policy through increase managerial ownership.

\section{Validation of the Hypothesis}

\section{Hypothesis I}

$\mathbf{H O}_{1}$ : Managerial ownership has no significant effect on firm value of listed manufacturing companies in Nigeria.

The variable used to test the formulated hypothesis shows that the p-value $(<0.1)$ of managerial ownership was statistically significant as $10 \%$ level of significant. This shows that $\mathrm{H}_{0}$ was rejected in favour of alternative hypothesis. As a result of this, the study validated that managerial ownership has significant effect on firm value of selected listed manufacturing companies in Nigeria. Studies like Rudiger and Rene (2009) and Wenjuan et al. (2009) arrived at the same conclusion.

\section{Hypothesis II}

$\mathbf{H O}_{2}$ : Dividend payment policy has no significant indirect role on firm value of listed manufacturing companies in Nigeria.

The estimated standard error (1.0154) and the critical values (2.042) were significantly different from zero using Judd and Kenny (1981) approach. Therefore, confirmed dividend payment policy has significant indirect effect on firm value. Therefore, the formulated $\mathrm{H}_{\mathrm{o}}$ was rejected in favour of the alternative hypothesis. 


\section{Conclusion and Recommendations}

The findings from this study established that there was a partial mediation of managerial ownership, dividend payout and leverage ratio on firm value. It was confirmed that managerial ownership had an indirect and significant effect on firm value; while, leverage ratio and dividend payout ratio showing a direct and significant effect on it. On mediation, it was confirmed that dividend payout through managerial ownership indirectly contributed $33.1 \%$ to firm value. Therefore, concludes that managerial ownership and dividend payment policy partly contribute to firm value with dividend payment policy playing an indirect role through increase in managerial ownership. Given this, the following recommendations are made;

i. Organizations should endeavor to review their dividend payment policy and ensure that dividend accrue to the firms' coffer are pay as at when due. The finding has established that dividend payout indirectly mediates in ownership structure through managerial ownership; therefore, becomes necessary for an organization to regularly designing a dividend payment policy that will improve shareholders' value.

ii. Managers of listed firms are strongly advised to take more of long-term loan on intending capital projects. On leverage ratio, it was confirmed that leverage ratio was significant and had a direct effect on firm value. This therefore, becomes necessary for an organization that combine both the debts and equity to finance its operation with a long-term loan in order to increase the return on assets as well as dividend receive by each shareholder.

iii. The shareholder should embrace bird in hand theory for future gain and reduce the volume of retained earnings through regular distribution of dividends in order to reduce the use of such funds for personal usage by manager.

\section{Reference}

Adenugba, A. A., Ige, A. A. and Kesinro, O. R. (2016). Financial leverage and firms' value: a study of selected firms in Nigeria. European Journal of Research and Reflection in Management Sciences, 4(1): 20-26.

Ahmad, M. O. G. and Abdul Aziz, A. A. (2017). Factors influencing firm value as measured by the Tobin's Q: Empirical evidence from the Saudi Stock Exchange (TADAWUL). International Journal of Applied Business and Economic Research, 15(6): 34-45.

Akani, H. W. and Kenn-Ndubuisi, J. I. (2017). Effects of Capital Structure and Board Structure on Corporate Performance of Selected Firms in Nigeria (2008 -2016). Indian Journal of Finance and Banking, 2(1): 2550-70.

Ang, J. S., Cole, R. A. and Lin, J. U. (2000). Agency Cost and Ownership. The Journal of Finance, 9(1): 81-106.

Anton, S. G. (2016). The Impact of Dividend Policy on Firm Value. A Panel Data Analysis of Romanian Listed Firms. Journal of Public Administration, Finance and Law, 3(3): 23-41.

Duc, H. and Van, T. N. (2014). Managerial ownership, leverage and dividend policies: Empirical evidence from Vietnam's listed firms. International Journal of Economics and Finance, 6(5): 2034.

Gitagia, F. K., Wamugo, L. and Omagwa, J. (2020). Dividend decisions, economic growth and firm's value of firms listed at Nairobi Securities Exchange Kenya. Research Journal of Finance and Accounting, 11(18): 41-48.

Gujarati, D. N., Porter, D. C. and Gunesekar, S. (2012). Basic Econometric (5th ed.). New York: The McGraw-Hill Companies.

Hamid, U., A. F. and Shafiullah, K. (2012). The impact of ownership structure on dividend policy evidence from emerging markets KSE-100 index Pakistan. International Journal of Business and Social Science, 3(9): 10-22.

Harada, K. and Nguyen, P. (2011). Ownership concentration and dividend policy in Japan. Managerial Finance, 37(4): 362-79.

Haryono, U. and Paminto, A. (2015). Corporate Governance and Firm Value: The Mediating Effect of Financial Performance and Firm Risk. European Journal of Business and Management, 7(35): $18-24$.

Ishola, J. A. and Ishola, O. P. (2019). Corporate Social Responsibility: Its Effects on the Performance of Insurance Sector in Nigeria. Ilorin Journal of Human Resource Management (IJHRM), 3(2): 1932. 
Jensen, M. (1986). Agency costs of free-cash-flow, corporate finance, and takeovers. American Economic Revision, 76: 323-29.

Jensen, M. C. and Meckling, W. H. (1976). Theory of the Firm: Managerial Behavior, Agency Costs and Ownership Structure. Journal of Financial Economics, 3: 305-60.

Judd, C. M. and Kenny, D. A. (1981). Process Analysis: Estimating Mediation in Treatment Evaluations. Evaluation Review, 5(5): 602-19.

Kaldor, N. C. (1966). Marginal productivity and the macro-economic theories of distribution: comment on Samuelson and Modigliani. The Review of Economic Studies, 33(4): 309-19.

Kuben, R. (2008). Financial leverage and firm value. MSc. . Dissertation, University of Pretoria:

Lebi, S. O. (2021). Oil revenue and manufacturing sector output in Nigeria: The case of Dutch Disease. Master Science dissertation, Adekunle Ajasin University, Akungba-Akoko, Ondo-State, Nigeria:

Lihard, S. L. and Ramon-Arthur, F. T. (2017). The effect of dividend policy, firm size, and productivity to the firm value. Research Journal of Finance and Accounting, 8(22): 20-37.

Linna, I. (2018). The influence of capital structure and dividends policy to firms value listed at Indonesian Stock Exchange. Advances in Social Science, Education and Humanities Research, 2(2): 8-13.

Lintner, J. (1956). Distribution of Incomes of Corporations Among Dividends, Retained Earnings, and Taxes. American Journal of Economic Review, 4(6): 97-113.

Mahdi, F. and Alireza, Z. (2017). The relationship between ownership and dividend policy: Evidence from Tehran Stock Exchange. International Journal of Economics and Financial, 7(2): 664-70.

Maladjian, C. and Rim, K. (2014). Determinants of the dividend policy: An empirical study on the Lebanese listed bank. International Journal of Economics and Finance, 6(4): 31-40.

Marvadi, C. R. (2015). Determinants of shareholder value creation in Indian banking sector. International Journal of Business and Administration Research Review, 1(12): 75-84.

Meragal, P. S. and Senadheera, P. G. (2016). The Impact of financial leverage on firms' value: Special reference to listed manufacturing companies in Sri-Lanka. International Journal Of Advancement In Engineering Technology, Management and Applied Science, 3(7): 100-04.

Miller, M. and Modigliani, F. (1961). Dividend policy, growth and the valuation of shares. The Journal of Business, 34(4): 411-33.

Ming-Chang, C. and Zuwei-Ching, T. (2011). The effect of leverage on firm value and how the firm financial quality influence on this effect. World Journal of Management, 3(2): 30-53.

Moeljadi. (2014). Factors affecting firm value: Theoretical study on public manufacturing firms in Indonesia. South-East Asia Journal of Contemporary Business, Economics and Law, 5(2): 23-44.

Mohammad, A., Ziad, Z. and Khaled, A. (2013). The effect of ownership structure on dividends policy in Jordanian companies. Interdisciplinary Journal of Contemporary Research in Business, 4(9): 32 41 .

Mueller, E. and Spitz, A. (2014). Managerial Ownership and Company Performance in German Small and Medium-Sized Private Enterprises. German Economic Review, 7(5): 233-47.

Muriungi, A. and Mwangi, M. (2020). Dividend theory and empirical evidence: a theoretical perspective. Journal of Accounting, Finance and Auditing Studies, 2(3): 20-34.

Nduta, C. N. (2016). The effect of dividend policy on the financial performance of firms listed at the Nairobi securities exchange. Master Theses - College of Humanities and Social Sciences.:

Panji, P. and Elan, K. (2018). Effect of managerial ownership and profitability on firm value: Empirical study on food and beverage industrial sector company 2012 to 2015. European Journal of Business and Management, 10(25): 20-28.

Priya, K. and Nimalathasan, B. (2013). Dividend policy ratios and firm performance: A case study of selected hotels \& restaurants in Sri Lanka. Global Journal of Management Perceptive, 3(3): 45163.

Priya, P. V. and Mohanasundari, M. (2016). Dividend policy and its impact on firm value: A review of theories and empirical evidence. Journal of Management Sciences and Technology, 3(3): 34-45.

Rachid, M. and Wiame, B. (2016). The relationship between dividend payments and firm performance: A study of listed companies in Morocco. European Scientific Journal, 12(4): 41-56.

Rahman, A. (2018). Effect of dividend policy on firm's performance: a case study of cement sector of Pakistan. SEISENSE Journal of Management, 1(5): 28-36.

Rozeff, M. S. (1982). Growth, beta and agency costs as determinants of dividend payout ratios. Journal of Financial Research, 5(3): 249-59.

Ruan, W., Tian, G. and Ma, S. (2011). Managerial ownership, capital structure and firm value: Evidence from China's Civilian-run firms. Australasian Accounting, Business and Finance Journal, 5(3): 73-92. 
Rudiger, F. and Rene, M. S. (2009). Managerial ownership dynamics and firm value. Journal of Financial Economics, 92(9): 342-61.

Samuel, A. and Edward, M. (2011). Dividend Policy and Bank Performance in Ghana. International Journal of Economics and Finance, 3(4): 34-49.

Sang-Mook, L. and Keunkwan, R. (2003). Management Ownership and Firm's Value: An empirical analysis using Panel Data. Discussion Paper No. 593. The Institute of Social and Economic ResearchOsaka University6-1 Mihogaoka, Ibaraki, Osaka 567-0047, Japan:

Sindhu, M. I., Hashmi, S. H. and Haq, E. U. (2016). Impact of ownership structure on dividend payout in Pakistani non-financial sector. Cogent Business \& Management, 3(4): 34-53.

Sourav, H., Abhijit, S. and Kalpataru, B. (2020). Impact of dividend policy on firm value with special reference to financial crisis. Journal of Management, 10(2): 158-75.

Stulz, R. (1988). Managerial Control of Voting Rights: Financing Policies and the Market For Corporate Control. Journal of Financial Economics, 20: 25-54.

Sundaram, A. and Inkpen, A. (2004). The Corporate Objective Revisited. Electronic Journal, 2(1): 23-41.

Thanatawee, Y. (2013). Ownership structure and dividend policy: Evidence from Thailand. International Journal of Economics and Finance, 5(1): 121-32.

Tian, G. G., Ruan, W. and Ma, S. (2009). Managerial ownership, capital structure and firm value. 71-82. http://ro.uow.edu.au/commpapers/690

Umar, A. I. and Abdul-Qudus, I. (2020). Effect of financial leverage on firm value: Evidence FromSelected Firms Quoted on the Nigerian Stock Exchange. European Journal of Business and Management, 12(3): 20-30.

Wahyudi, U. and Pawestri, H. P. (2006). Implikasi Struktur Kepemilikan Terhadap Nilai Perusahaan: dengan Keputusan Keuangan sebagai Variabel Intervening. Simposium Nasional Akuntansi, Padang, 9: 1-25.

Walter, J. E. (1963). Dividend Policy: Its Influence on the Value of the Enterprise. Journal of Finance, 18: 280-91.

Wenjuan, R., Gary, T. and Shiguang, M. (2009). Managerial ownership and firm value: Evidence from China's civilian-run firms. Researchgate: 